„Kwartalnik Filmowy” nr 111 (2020)

ISSN: 0452-9502 (Print) ISSN: 2719-2725 (Online)

https://doi.org/10.36744/kf.367

(c) Creative Commons BY-NC-ND 4.0

Krzysztof Loska

Uniwersytet Jagielloński

https://orcid.org/0000-0003-4078-798X

\title{
Pamięć, performans i afekty - temat ludobójstwa w filmach Joshui Oppenheimera
}

\footnotetext{
Slowa kluczowe:

ludobójstwo; Indonezja; film dokumentalny; teoria afektów; performans

\begin{abstract}
Abstrakt
Punktem wyjścia refleksji nad filmami Joshui Oppenheimera jest koncepcja performansu w ujęciu Rebeki Schneider zwłaszcza jej uwagi na temat historycznych rekonstrukcji oraz teoria afektów w ujęciu Jill Bennett (ponieważ rzeczywistym skutkiem praktyk performatywnych jest „afektywne poruszenie"). W proponowanym przez autora odczytaniu Sceny zbrodni (2012) i Sceny ciszy (2014) to właśnie zarejestrowane przez reżysera historyczne performanse wraz z ich zdolnością oddziaływania na emocje, czyli wywoływania określonych reakcji afektywnych (wstręt, obrzydzenie, współczucie, fascynacja), są metodą, za pomocą której można mówić o ludobójstwie w nowy sposób. Wychodząc od analizy filmów Oppenheimera, autor zastanawia się nad tym, w jaki sposób jest konstruowana i rekonstruowana pamięć o wydarzeniach historycznych, do jakiego stopnia przeszłość wpływa na teraźniejszość, a wreszcie, czy możliwe jest obserwowanie siebie niejako „z zewnątrz”, by zmierzyć się z własnymi afektami.
\end{abstract}


Filmy dokumentalne opowiadające o ludobójstwie, czystkach etnicznych i masowych mordach zazwyczaj skupiają się na relacjach ocalonych - jak Shoah (1985) Claude'a Lanzmanna - lub świadectwie następnych pokoleń zmagających się ze stratą. W ostatnich latach wiele uwagi poświęca się także problematyce postpamięci, która jest związana z międzypokoleniowym przekazywaniem traumatycznego doświadczenia, życiem w cieniu minionych wydarzeń, niejako w zawieszeniu między czasem teraźniejszym i przeszłym ${ }^{1}$. W swoim artykule pragnę jednak zwrócić uwagę na filmy, których twórcy zmieniają perspektywę i kierują obiektyw kamery na sprawców okrutnych zbrodni, narażając się na zarzuty o nieetyczne praktyki, moralną dwuznaczność, zamazywanie granicy między ofiarami i katami oraz proponowanie narracji o odkupieniu winy².

Primo Levi pisał, że oprawcy nierzadko są jedynymi świadkami popełnionych zbrodni, ponieważ nikt nie wrócił, aby opowiedzieć o swojej śmiercỉ. Być może dlatego warto uwzględnić ich świadectwo, nawet jeśli nie uznają oni wagi swoich czynów, przyjmują postawę obronna, nie okazują współczucia i nie potrafią nawiązać relacji z osobami, które przeżyły traumę (lub ich krewnymi). Wychodząc od filmów Oppenheimera poświęconych indonezyjskiemu ludobójstwu, zamierzam zastanowić się nad tym, w jaki sposób jest konstruowana (i rekonstruowana) pamięć o wydarzeniach historycznych, do jakiego stopnia przeszłość wpływa na teraźniejszość (zmuszając ocalonych do życia z widmami), a wreszcie, czy możliwe jest obserwowanie siebie niejako „z zewnątrz”, by zmierzyć się z własnymi afektami.

W dwóch filmach - Scenie zbrodni (The Act of Killing, 2012) i Scenie ciszy (The Look of Silence, 2014) - Joshua Oppenheimer przypomina o masakrach ludności, do jakich doszło w Indonezji między październikiem 1965 a marcem 1966 r. (do dymisji podał się prezydent Sukarno, a jego miejsce zajął generał Suharto). Tragedię zapoczątkował nieudany zamach stanu przeprowadzony w nocy z 30 września na 1 października przez grupę oficerów, którzy uprowadzili i zamordowali sześciu wysokich rangą generałów (z szefem sztabu na czele) ${ }^{4}$. Pomimo że do dziś nie ma pewności, z czyjej inspiracji działali spiskowcy, to wówczas za przewrót obwiniono sympatyków partii komunistycznej. Próba puczu wojskowego została zdławiona w zarodku, a członkowie "Ruchu 30 Września” (Gerakan 30 September, w skrócie G30S) - jak nazywali siebie organizatorzy - aresztowani przez generała Suharto, który ogłosił plan oczyszczenia kraju z komunistów i działaczy związkowych. W kolejnych dniach, najpierw w północnej części Sumatry, zamieszkanej przez ludność wyznania muzułmańskiego, rozpoczęto eksterminację podejrzanych oraz ich rodzin. Za masowymi mordami stały paramilitarne bojówki młodzieżowe (m.in. Pemuda Pancasila) i stowarzyszenia religijne, nieoficjalnie wspierane i zbrojone przez armię.

Kilka dni po udaremnionym zamachu ruszyła machina propagandowa, obliczona z jednej strony na wywołanie paniki wśród obywateli, z drugiej zaś na przekonanie ich do poparcia czystek, a nawet przyłączanie się do samosądów. W mediach przeważały informacje na temat potencjalnego zagrożenia ze strony komunistów, których demonizowano i przedstawiano jako zwyrodniałych bezbożników pijących ludzką krew, pozbawionych wszelkich zasad moralnych i żyjących w wolnych związkach. W kraju zapanowały rządy przemocy i chaos członkowie szwadronów śmierci palili całe wsie, mieszkańców wywozili w nie- 
znane i tam ich zabijali. Jak pisze Natalia Laskowska, ofiarom obcinano głowy, ręce, nogi i porzucano zwłoki w lasach lub wrzucano do rzek. (...) Komunistyczna stygmatyzacja przez kolejne trzy dekady pozbawiała rodziny ofiar petnych praw obywatelskich, zaś wszelkie oskarżenie lub podejrzenie o lewicowe poglady groziło utrata życia ${ }^{5}$.

W ciągu sześciu miesięcy w masowych mordach zginęło co najmniej pół miliona ludzi (niektóre źródła podają znacznie większą liczbę ofiar), a sprawców zbrodni nigdy nie ukarano, ponieważ w oficjalnej narracji narodowej uchodzili za bohaterów, podczas gdy zabici - za zdrajców. Indonezyjskie władze uznały czystki polityczne za działania "spontaniczne" i usprawiedliwione, podjęte w obronie integralności kraju, dlatego odrzucały oskarżenie o ludobójstwo. Przyjęte przez prezydenta Suharto podejście wydaje się typową strategią każdego państwa, w którym doszło do masowych zbrodni. Rządy autorytarne zawsze reagują oburzeniem na wszelkie zarzuty o współudział w aktach przemocy, do jakich dochodzi na ich terytorium, a przy tym szukają winnych na zewnątrz, zgodnie z kierunkiem własnej polityki historycznej ${ }^{6}$.

Pierre Bourdieu i Jean-Claude Passeron formułują tezę, że każda władza o przemocy symbolicznej, to znaczy każda wtadza, której udaje się narzucić znaczenia, $i$ to narzucić je jako uprawnione, ukrywajac układy sił leżace u podstaw jej mocy, dorzuca do owych układów sił swoja własna moc, to znaczy moc czysto symboliczna ${ }^{7}$. Panowanie symboliczne nie ogranicza się do stosowania przemocy, ale wytwarza również efekty czysto pedagogiczne, czyli narzuca społeczeństwu w sposób arbitralny określoną interpretację faktów w celu ochrony własnych interesów. Jednym z narzędzi indonezyjskiego dyskursu pedagogicznego był wyprodukowany na zlecenie rządu czteroipółgodzinny dokument propagandowy Pengkhianatan G30 September/PKI (reż. Arifin C. Noer, 1984), utrwalający oficjalną interpretację wydarzeń z 1965 r., zgodnie z którą całkowitą odpowiedzialność za tragedię ponosili członkowie i sympatycy partii komunistycznej, pomimo że to oni tracili życie w systematycznie przeprowadzanych czystkach ${ }^{8}$.

Ludobójstwo jest zbrodnią zdefiniowaną w prawie międzynarodowym, przede wszystkim w konwencji uchwalonej przez Zgromadzenie Ogólne Narodów Zjednoczonych 9 grudnia 1948 r. ${ }^{9}$ W tym klasycznym rozumieniu, opartym na propozycji polskiego prawnika Rafała Lemkina, chodzi o zaplanowaną eliminację grup narodowych, etnicznych, rasowych lub religijnych. Zakres tego pojęcia nie uwzględnia jednak zbrodni motywowanych politycznie lub kulturowo, dlatego Joshua Oppenheimer przyjmuje ogólniejszą definicję Helen Fein, która za ludobójstwo uznaje podtrzymywane, celowe działanie sprawców, zmierzające do fizycznego zniszczenia wspólnoty, zarówno bezpośrednio, jak i pośrednio, przez wstrzymywanie biologicznej i społecznej reprodukcji członków grupy, kontynuowane bez względu na poddanie się ofiar lub też brak rzeczywistego zagrożenia zich strony ${ }^{10}$.

Zrealizowane przez Joshuę Oppenheimera filmy dokumentalne stanowią ważny głos w debacie na temat sposobów reprezentacji ludobójstwa, przyczyn przemilczania masowych zbrodni oraz ich uwikłania w dyskurs władzy i politykę pamięci, która - jak stwierdza Tomasz Łysak - jest źródłem wiedzy o funkcjonowaniu instytucji przemocy ${ }^{11}$. Amerykański reżyser nie jest jednak socjologiem ani historykiem, dlatego nie wypowiada się na temat przyczyn i przebiegu wydarzeń, lecz skupia się na indywidualnych przypadkach, mikrohistoriach, by posłużyć się określeniem zaczerpniętym od Ewy Domańskiej ${ }^{12}$. Podejście to wynika z przekonania, 
że przeszłość nie jest czymś danym obiektywnie, lecz raczej wyobrażonym - swoistym miejscem fantazji, w którym rzeczywistość splata się z realnościa emocji i uczuć ${ }^{13}$.

Joshua Oppenheimer nie opisuje tego, co wydarzyło się w 1965 r., nie tłumaczy źródeł przemocy, lecz pyta o to, co się stało z ludźmi, którzy brali udział w masakrach, jak po latach oceniają samych siebie i własne uczynki, a wreszcie o to, jaką cenę zapłaciło społeczeństwo za milczenie o przeszłości, która - w sposób widmowy - jest obecna w życiu codziennym Indonezyjczyków ${ }^{14}$. Niektórzy krytycy zarzucali reżyserowi, że skupił się wyłącznie na subiektywnym przeżywaniu historii przez jej uczestników, że nieobecność komentarza autorskiego określającego ramy interpretacyjne i etyczne doprowadziła do zniekształcenia perspektywy, zawieszenia wiary w możliwość dotarcia do prawdy. Postawa reżysera wynikała z przyjęcia określonego sposobu reprezentacji przeszłości, opierała się na wykorzystaniu podejścia rekonstrukcyjnego (reenactment), którego zasadniczym składnikiem jest aspekt performatywny. Film dokumentalny stwierdza Oppenheimer - jest tworzeniem pewnej rzeczywistości i nie należy ukrywać performatywnej natury niefikcjonalnych przedstawień, ponieważ ludzie zawsze odgrywają jakieś role ${ }^{15}$. Stylizowane sceny rekonstrukcyjne służą odsłonięciu ideologicznej natury "fantazmatycznych" obrazów wytwarzanych przez sprawców zbrodni, a zarazem wykazaniu, że media kształtują zbiorową pamięć o przeszłości. Można powiedzieć, że to właśnie skupienie się na performansie sprawców okazuje się narzędziem ułatwiającym podważenie dominującej narracji historycznej oraz sposobem na pokazanie tego, w jaki sposób duchy ofiar towarzyszą swym katom.

Jak uważa Rebecca Schneider, w praktykach rekonstrukcyjnych nie chodzi o przypominanie minionych wydarzeń, ale o ich aktualizację w teraźniejszości ich widmową obecność - ponieważ tym, co pozostaje z przeszłości, są jedynie resztki fragmentarycznie odtwarzane przez ciała uwikłane w sieć afektów ${ }^{16}$. W proponowanym przeze mnie odczytaniu Sceny zbrodni i Sceny ciszy to właśnie zarejestrowane przez reżysera historyczne performanse, wraz z ich zdolnością do oddziaływania na emocje, czyli wywoływania określonych reakcji afektywnych (wstręt, obrzydzenie, współczucie, fascynacja), pozwalają mówić o ludobójstwie w nowy sposób. Joram ten Brink i Joshua Oppenheimer we wstępie do książki Killer Images pisza, że rekonstrukcja jest nie tylko narzędziem krytycznym, za pomocą którego można analizować wpływ przeszłości na teraźniejszość, ale również strategią filmową umożliwiającą przedstawienie przemocy na ekranie oraz przywoływanie wspomnień i aktualizację pamięci cielesnej ${ }^{17}$.

Metodologicznym punktem odniesienia w refleksji nad filmami Oppenheimera są dla mnie zarówno publikacje Rebeki Schneider i Diany Taylor poświęcone performansowi - zwłaszcza historycznym rekonstrukcjom, które stanowią rodzaj pamięci wcielonej - jak i teoria afektów w ujęciu Jill Bennett, ponieważ rzeczywistym skutkiem praktyk performatywnych jest afektywne poruszenie ${ }^{18}$. Inscenizowanie i odgrywanie minionych wydarzeń pozwala na przywołanie sytuacji, w których uczestnicy odczuwali pewne emocje. Afekt tworzy rzeczywiste doświadczenie somatyczne - stwierdza Bennett - dlatego w procesie przywoływania wspomnień wychodzi się od ciała ${ }^{19}$. Również dla Oppenheimera ciało jest nośnikiem pamięci, a zarazem miejscem krzyżowania się czasowości (cross-temporality), by posłużyć się 
określeniem Schneider - czyli przenikania się przeszłości i teraźniejszości ${ }^{20}$. Można się zgodzić z tezą Thomasa Patricka Pringle'a, który uważa, że Scena zbrodni jest $\mathrm{w}$ większym stopniu afektywna etnografia traumatycznego wydarzenia niż pedagogicznym opisem historycznych faktów dotyczących ludobójstwa ${ }^{21}$.

Każda rekonstrukcja (reenactment) jest oparta na performatywnym powtórzeniu, czyli podważeniu granicy między pierwotnym wydarzeniem a jego ponownym odegraniem, co prowadzi do zakwestionowania linearnego modelu czasu, a następnie zmusza do krytycznego namysłu oraz poszukiwania nowych sposobów przepracowania przeszłości. Praktyka performatywna pozwala - jak pisze Dorota Sajewska - na skrajnie subiektywne i zmysłowe doświadczenie historii, a zarazem na artystyczna refleksje nad mechanizmami pamiętania $i$ zapominania, nad statusem źródet, świadectw i dokumentów, nad fikcjonalnym charakterem dokumentacji i performatywnym potencjałem procesów archiwizacji ${ }^{22}$.

Afekt i performans są ze sobą splecione - oba pojęcia łączą się z działaniem, zdolnością do pobudzania i bycia pobudzonym, wpływaniem na innych i uleganiem wpływowi ${ }^{23}$. Wszelkie skutki tych poczynań znajdują swój „zapis” na ciele, które odczuwa radość, ból, rozkosz, cierpienie i przechowuje ich ślady, a nawet konteksty, w jakich doznania te pojawiły się (o ile zostały następnie powtórzone). Performatywnie dookreślona afektywność - zgodnie z łacińskim źródłosłowem ("affectus", "afficere" - działać, wyrządzać coś) - jest postrzegana jako intencjonalne, instynktowne lub samorzutne działanie skierowane na kogoś - stwierdza Tomasz Dolasiński ${ }^{24}$.

Przygotowania do realizacji filmów na temat ludobójstwa Oppenheimer rozpoczął na początku obecnego stulecia, kiedy to po raz pierwszy spotkał się ze sprawcami masakry w północnej Sumatrze i przekonał ich do udziału w swoim projekcie. Zarejestrowane wówczas materiały posłużyły jako punkt wyjścia dysertacji doktorskiej; niektóre z nich wykorzystał później w Scenie ciszy, w której opisał podstawowe założenia metody realizacyjnej, stosowane zresztą z powodzeniem w kolejnych filmach. Chcąc przypomnieć o tragicznych wydarzeniach z przełomu 1965 i 1966 r., nie zamierzał sięgać do dokumentów archiwalnych, ale postanowił zachęcić uczestników do opowiedzenia o popełnionych zbrodniach i odegrania ich na planie. Amerykański reżyser wyraźnie podkreśla konsekwencje performatywnego podejścia do historii i zastosowania praktyk rekonstrukcyjnych, w wyniku których dochodzi do przeniesienia przeszłości w teraźniejszość, wyrwania wydarzenia z jego pierwotnego kontekstu przez stylizowane powtórzenie aktów ${ }^{25}$. Oppenheimer odwołuje się do propozycji teoretycznych Judith Butler, która pisała, że powtórzenie stanowi ponowna realizację (",reenactment") całego społecznie przyjętego zbioru znaczeń, a także jego ponownego doświadczenia i że to ciała konkretnych jednostek inscenizuja owe znaczenia poprzez stylizacje $e^{26}$.

Rekonstrukcja wydarzeń historycznych nie jest bynajmniej strategią estetyczną rzadko spotykaną w filmach dokumentalnych; artyści od dawna się nią posługują (m.in. Harun Farocki czy Jeremy Deller), łącząc inscenizację ze zdjęciami archiwalnymi (czyni tak Patricio Guzmán w Chile, la memoria obstinada /1997/, odtwarzając okoliczności zamachu stanu, w wyniku którego obalono prezydenta Salvadora Allende) lub wykorzystując ją jako narzędzie dystansujące, jak Werner Herzog w Maty Dieter chciałby latać (Little Dieter Needs to Fly, 1997). Bill Nichols przekonująco uzasadnia, że w Scenie zbrodni chodzi jednak o coś innego - nie tyle o obiektywne przedstawienie przeszłości, ile o subiektywną jej interpretację za- 


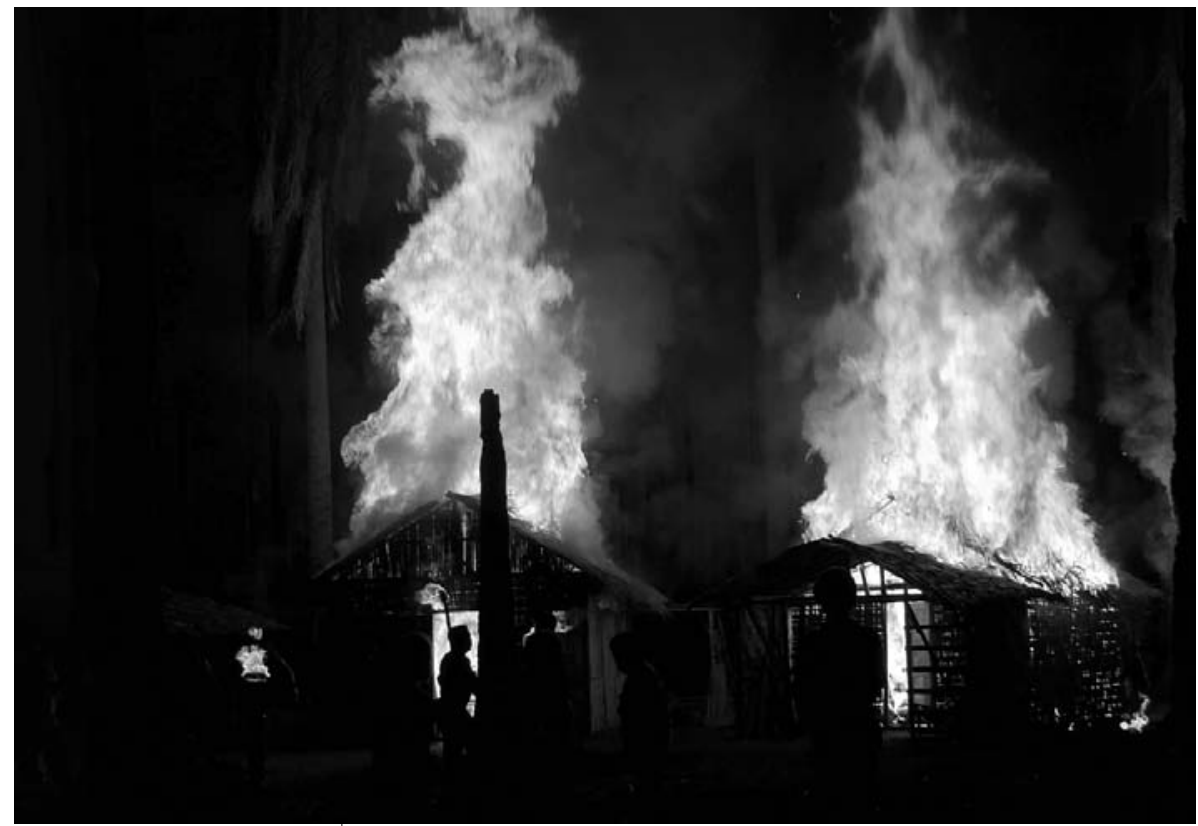

Scena zbrodni, reż. Joshua Oppenheimer (2012)

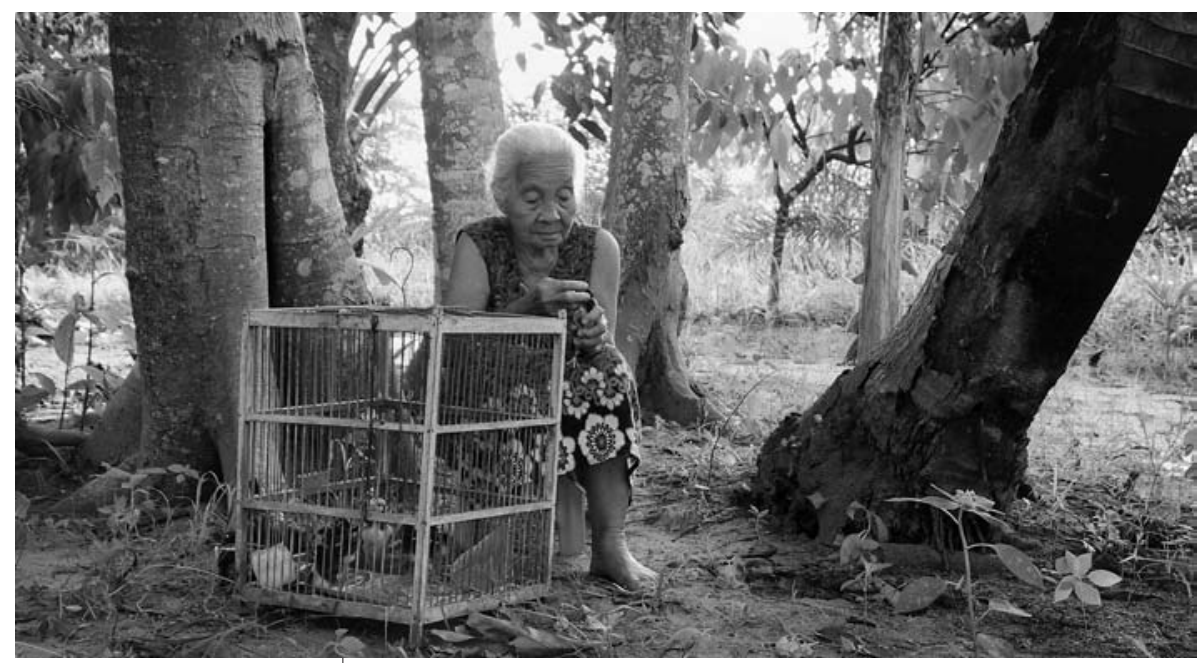

Scena ciszy, reż. Joshua Oppenheimer (2014) 
proponowaną przez bohaterów filmu, którzy w młodości brali udział w eksterminacji komunistów ${ }^{27}$.

Poszukując formy zdolnej oddać złożoną historię, Joshua Oppenheimer zrezygnował z narracji linearnej i wybrał strukturę hybrydyczną. Rozmowy z uczestnikami tragicznych wydarzeń sprzed lat przeplatają się ze stylizowanymi rekonstrukcjami, które następnie zmieniają się w dziwaczny spektakl przypominający niskobudżetowe kino eksploatacji (exploitation movie), wypełnione odniesieniami do klasycznych gatunków hollywoodzkich. Odgrywający swe zbrodnie członkowie szwadronów śmierci wielokrotnie wspominają o filmach z udziałem Johna Wayne'a, Marlona Brando, Ala Pacino i Sidneya Poitier, na których pragną się wzorować. Starzejący się mężczyźni otwarcie opowiadają o swych uczynkach, gdyż wiedza, że pozostaną bezkarni. Szczycą się nimi i bez wahania odtwarzają przed kamera, demonstrując, jak torturowali i zabijali pojmanych więźniów ${ }^{28}$. Ich buńczuczne wypowiedzi wywołują dezorientację i niedowierzanie. Wcielona pamięć uchwycona przez reżysera w performatywnych rekonstrukcjach zbrodni oddziałuje na widzów na poziomie afektywnym, wzbudza nie tylko uczucie obrzydzenia, lecz - do pewnego stopnia - także fascynacji ${ }^{29}$. Oczywiście oglądanie inscenizacji dawnych wydarzeń polega nie na biernym poddaniu się interpretacji zaproponowanej przez „aktorów”, ale przyjęciu krytycznego dystansu wobec ich wersji wydarzeń.

Pierwsza sekwencja rekonstrukcyjna w Scenie zbrodni została zarejestrowana na dachu jednego z budynków, gdzie Anwar Congo - drobny przestępca, który w latach 60. utrzymywał się z pobierania haraczy od właścicieli kin - dokonywał egzekucji za pomoca garoty. On i jemu podobni mordercy proponują fantazmatyczną reprezentację zarówno przeszłości, jak i teraźniejszości, ponieważ kreują się na obrońców narodu i bohaterów ludowych. Przyjęta przez nich postawa jest mechanizmem obronnym, za pomocą którego radzą sobie z poczuciem winy i odsuwają wszelkie wątpliwości co do oceny moralnej swojego postępowania. Primo Levi w Pograżonych i ocalonych pisał, że oprawcy zawsze szukają usprawiedliwienia, przekształcają niewygodne wspomnienia i wypierają je lub sprowadzają do akceptowalnej postaci. Proces ten wiedzie do momentu, w którym sam bezpośrednio zainteresowany nie umie już oddzielić prawdy od fatszu, nie potrafi dociec, jak wygladaty pierwotnie zapamiętane wydarzenia - stwierdza Sławomir Buryła ${ }^{30}$.

Podczas wizyty na dachu budynku Anwar tańczy cza-czę i mówi o zabijanych komunistach, o tym, jak pozbywał się ciał i radził sobie z potokiem krwi. Epizod ten zapowiada jeden z głównych tematów filmu, czyli wpływ przeszłości na teraźniejszość i związaną z tym możliwość przedstawienia spektralnej historii kraju (Żyje w tym miejscu wiele duchów, ponieważ zabiliśmy tu mnóstwo ludzi). Problematyzuje przy tym status rekonstrukcji, przede wszystkim za sprawą przebitek, w których Anwar ogląda i komentuje zarejestrowane wcześniej materiały (Z pewnościa nie założyłbym białych spodni do egzekucji - mówi). Ekran telewizyjny, na którym jest wyświetlany zapis performansu, stanowi narzędzie autorefleksyjne. Pozwala na obnażenie mechanizmu przemocy przez odsłonięcie luki istniejacej między przedstawieniem a realnościq - uważa Emma Willis; to zaś pozwala zbliżyć sprawców do "duchów” ich ofiar (bohater kilkakrotnie wspomina o nawiedzających go koszmarach) ${ }^{31}$.

Widmowa obecność zamordowanych komunistów jest skutkiem nieprzepracowanej traumy oraz tego, że ludobójstwo nigdy nie zostało oficjalnie uznane. 
Dlatego też Lucien van Liere odczytuje film jako przykład dyskursu spektralnego - indonezyjską opowieść o opętaniu przez duchy (kemasukkan) oraz przywoływaniu ich przez medium (panggil roh), czyli Anwara Congo ${ }^{32}$. Zmarli są jak upiory, pozbawione możliwości pochówku i zapomniane, które nawiedzają swoich oprawców, ukazują się im w koszmarach sennych i patrzą na nich pustymi oczodołami (wspomina o tym nie tylko Anwar, ale i Adi Zulkardy, najbardziej cyniczny z występujących w filmie zbrodniarzy). Zgodnie z logiką nawiedzania widmo jest zawsze tym, co powraca i czego nie sposób kontrolować, co stanowi zagrożenie i wymaga egzorcyzmowania za pomocą aktów performatywnych, w których buńczuczne opowieści są wspierane przez stylizowane rekonstrukcje.

Oprawcy ubarwiają swoje wspomnienia, wtłaczają je w ramy schematów gatunkowych (westernu, horroru i filmu gangsterskiego), co sprawia, że w większym stopniu przypominają one dokumentację wyobrażeń niż rekonstrukcję wypadków historycznych. Teatralność gestów wynika poniekąd z obecności kamery, ale dzięki przerysowaniu odsłania się performatywny wymiar spektaklu przemocy, uwarunkowany przez powtarzalność okrutnych czynów ${ }^{33}$. W inscenizacjach nie tylko odwołują się do własnych wspomnień, lecz posługują się kliszami zaczerpniętymi z wielokrotnie nadawanego w telewizji dokumentu propagandowego na temat wydarzeń sprzed lat. Przekonują o tym chociażby sceny prób do wyimaginowanego filmu Arsan i Aminah, który opowiada o miłości komunistki do członka prawicowej bojówki ${ }^{34}$. Fantazmatyczny wymiar performansów podkreślają również choreograficzne układy stylizowane na amerykańskie musicale. Tancerki ubrane w kolorowe stroje występują w sekwencji rozgrywającej się „W zaświatach”. Na tle malowniczego wodospadu jedna z ofiar wręcza Anwarowi medal za odwagę i dziękuje za odebranie życia. Homay King widzi w tej rewizjonistycznej fantazji nie tylko przykład projekcji życzeniowej i zniekształconej percepcji rzeczywistości, ale również świadomie przyjętą strategię dystansu ${ }^{35}$.

Oppenheimer podkreśla, jak ważną rolę pełnią autentyczne miejsca, do których zabierają go uczestnicy tragicznych wydarzeń, jak chociażby w scenach rekonstrukcji masakry w Kampung Kolam. Zgromadzeni statyści śpiewają patriotyczne pieśni i skandują hasła w rodzaju: Zabić komunistów. Wyrżnać ich wszystkich. Nie brać żadnych jeńców. Spalić ich domy i odciać głowy. Mężczyźni ubrani w mundury paramilitarnych bojówek Pemuda Pancasila podpalają chaty i przystępują do zainscenizowanych egzekucji, których wiarygodność potęgują jeszcze krzyki kobiet oraz płacz dzieci. Adi Zulkardy, przyjaciel Anwara, stwierdza na koniec: Będa nas przeklinać przez resztę życia... Wymordowaliśmy tych ludzi i nie spotkała nas żadna kara. Nic innego nie mogliśmy zrobić. Musimy się z tym pogodzić. Rodziny zmarłych nie doczekały się sprawiedliwości, zostały napiętnowane i wykluczone z przestrzeni publicznej, pozbawione możliwości zatrudnienia w urzędach państwowych, nierzadko zmuszone do opuszczenia rodzinnych stron.

Oppenheimer wielokrotnie tłumaczył, że oddanie głosu sprawcom wynikało z faktu, iż krewni ofiar bali się mówić, ponieważ wiedzieli, że oskarżając zabójców narażają się na zarzut popierania komunizmu. Reżyser zdawał sobie sprawę także $\mathrm{z}$ tego, że chcąc zrozumieć mechanizmy przemocy na poziomie zbiorowym i jednostkowym, musi uwzględnić perspektywę zbrodniarzy ${ }^{36}$. Nie bez znaczenia dla przyjętej strategii autorskiej była powszechna nieufność społeczeństwa indonezyjskiego wobec nielicznych wypowiedzi ocalałych, a co za tym idzie 
- potrzeba znalezienia innego sposobu opowiedzenia o ludobójstwie. Pozostaje jednak pytanie o status wyznań oprawców, kwestię wiarygodności i zaufania do ich relacji. Magdalena Marszałek uważa, że w tym wypadku nie mamy do czynienia ze świadectwem, bo ono wymaga motywacji etycznej - skruchy i pragnienia odpokutowania za winy. Jej opinia znajduje potwierdzenie w uwagach krytycznych niektórych badaczy uważających, że konieczna jest konfrontacja z perspektywą ofiary ${ }^{37}$.

Możliwość przyjęcia innego punktu widzenia pojawiła się dopiero w drugim filmie, Scenie ciszy, który można uznać za dopełnienie dyskursu na temat indonezyjskiego ludobójstwa. Zanim przejdę do jego krótkiego omówienia, pragnę najpierw zwrócić uwagę na jedyny fragment Sceny zbrodni, w którym wystąpiła ofiara prześladowań. Suryono opowiada o tym, jak członkowie paramilitarnej bojówki wkroczyli do domu ojczyma, wywlekli go na zewnątrz i zabili na oczach rodziny. W kolejnym ujęciu mężczyzna odgrywa rolę więźnia w rekonstrukcji brutalnego przesłuchania. Oprawcy wiążą mu ręce, zasłaniają oczy i przemocą zmuszają do zeznań. Podobna scena zostanie powtórzona z udziałem Anwara, który wciela się w postać torturowanego komunisty. Kiedy bohater ogląda zarejestrowany materiał na ekranie telewizyjnym, zadaje sobie pytanie: Czy ludzie, których skrzywdziłem, czuli to samo? Najpierw czułem się odarty z godności, potem przyszedt strach. I nagle trwoga opanowała moje ciało. (...) Czy to wszystko do mnie wróci? Mam nadzieję, że nie. Spoza kadru słychać głos reżysera: Tak naprawdę ludzie, których torturowateś, czuli się znacznie gorzej, ponieważ wiedzieli, że zginą․ Epizod ten można odczytać jako przykład obrazowania wtórnego - by się posłużyć określeniem Jill Bennett - w którym doświadczenie afektywne nie jest jedynie przywotywane za pomoca referencji, lecz (...) w pewien sposób inscenizowane ${ }^{39}$.

Zastanówmy się, czy mamy do czynienia z wyznaniem, czy tylko z pozą. Z prawdziwym żalem czy elementem spektaklu? Anwar do samego końca szuka usprawiedliwienia i tłumaczy, że musiał zabijać komunistów. Reżyser nie udziela jednoznacznych odpowiedzi na powyższe pytania i pozostawia widza w niepewności - ze względu na rezygnację z komentarza autorskiego oraz konsekwentne zamazywanie granicy między fikcją i realnością. Henrik Skov Nielsen odczytuje film jako opowieść o podróży egzystencjalnej, jaką odbywa główny bohater w głąb siebie, aby skonfrontować się ze stłumionymi wspomnieniami i duchami przeszłości ${ }^{40}$. Można jednak spojrzeć na to z innej strony i uznać Scenę zbrodni za świadectwo - co sugeruje Janet Walker - wyznanie winy poczynione przez sprawców okrutnych mordów (nawet jeśli przedstawione $\mathrm{w}$ formie fantazmatycznych inscenizacji) ${ }^{41}$.

Wielu krytyków zwraca szczególną uwagę na końcową sekwencję, która rozgrywa się podczas powtórnych odwiedzin Anwara Congo na dachu budynku (zdjęcia nakręcono kilka lat po pierwszej wizycie) ${ }^{42}$. Wydaje się, że bohater uświadamia sobie naturę popełnionych czynów, doznaje szoku, który objawia się w reakcji somatycznej (jego ciałem wstrząsają konwulsje). Jeśli obrzydzenie przekłada się na wrażenia trzewiowe, to - jak pisze Sarah Ahmed - nasza relacja z trzewiami nie jest bezpośrednia, ale zapośredniczona przez idee, które zawsze już wią̇a się z wrażeniami ${ }^{43}$. W ten sposób ujawnia się moc stylizowanej rekonstrukcji, w której przywołuje się coś, co istniało już wcześniej, ale co dzięki aktowi performatywnemu przybrało nową postać. Dzięki powtórzeniu czynności podmiot wpisuje się w zbrodnię, zaświadcza o swym współuczestnictwie, odczuwa wstręt do samego siebie. 
W Scenie ciszy Oppenheimer ponownie odwołuje się do mikrohistorii, jednak tym razem skupia się na losach ocalałych z ludobójstwa, którzy muszą żyć w sąsiedztwie sprawców, ukrywać swój ból i gniew z powodu rozlicznych zbrodni. Bohaterem jest Adi Rukun, urodzony w 1968 r., dwa lata po tragicznej śmierci starszego brata Ramliego zabitego przez członków Komando Aksi. Chcąc skonfrontować ofiarę z oprawcami, amerykański reżyser wykorzystuje nakręcone dziesięć lat wcześniej materiały, w których Amir Hasan Nasution i Inong Syah opowiadają o egzekucjach komunistów i odtwarzają sceny mordów, do których doszło nad Wężową Rzeką (Sungai Ular) ${ }^{44}$. Oppenheimer sięga do metafor optycznych, by zobrazować skutki „moralnej ślepoty” i wskazać drogę prowadzącą do odzyskania wzroku (czyli wyznania winy i pojednania). Przekonują o tym pierwsze ujęcia, w których bohater posługuje się urządzeniem optometrycznym, a potem ogląda film z udziałem ludzi odpowiedzialnych za śmierć brata.

W przeciwieństwie do poprzedniego dzieła, w Scenie ciszy reżyser sięgnął po konwencję dokumentu obserwacyjnego, zrezygnował z wprowadzenia scen fantazmatycznych i ograniczył rekonstrukcje. Adi Rukun odwiedza jednego ze sprawców pod pretekstem badania wzroku i wypytuje go o przeszłość. Starszy mężczyzna ze szczegółami opowiada o popełnionych zbrodniach, torturowaniu jeńców, piciu krwi wrogów i gwałtach popełnianych na kobietach, którym odcinano piersi ${ }^{45}$. Nie obawia się kary, ponieważ rodziny ofiar zostały uciszone. Przemocy fizycznej towarzyszy więc przemoc symboliczna, ponieważ zwycięzcom udało się narzucić powszechnie obowiązującą interpretację historii. Bohater pragnie jednak przełamać milczenie, ujawnić prawdę i zmusić przestępców do wzięcia odpowiedzialności za swoje czyny. Kamera towarzyszy mu nie tylko podczas spotkań z nimi, ale również w czasie rozmów z matka, która odgrywa rolę szczególna, ponieważ jej słowa zaświadczają o tym, że traumatyczne wydarzenia wciąż nawiedzają ocalonych, że przeszłość odciska swe piętno na ich teraźniejszym życiu.

Punktem zwrotnym w filmie jest wizyta w domu Amira Siahaana, jednego z dowódców szwadronów śmierci, który najpierw ze swadą opowiada o masakrach, a potem, gdy dowiaduje się, że jedną z ofiar był brat rozmówcy, zaprzecza bezpośredniemu udziałowi w jego zabójstwie i stwierdza, iż wykonywał polecenia przełożonych. Jedynie córka uświadamia sobie potworność zbrodni popełnionych przez ojca i ze łzami w oczach prosi gościa o przebaczenie. Sekwencja ta odzwierciedla paradoksalną sytuację, w której przestępcy przyznają się do mordów, lecz nie uznają się za winnych, nie biorą odpowiedzialności za swe uczynki i dopiero następne pokolenie jest gotowe do pojednania.

W Scenie ciszy główny bohater ogląda ilustrowane wspomnienia spisane przez Amira Hasana, w których narrator opowiada o swoich bohaterskich czynach, lecz akty przemocy pokazuje z punktu widzenia ofiar. Reżyser przekonuje, że sprawcy ludobójstwa postrzegali wydarzenia sprzed lat w kategoriach walki dobra ze złem toczaccej się na tle fantazmatycznej scenerii zaludnionej duchami. W komunizmie widzieli nadprzyrodzone zagrożenie, a jego wyznawców uznawali za obdarzone nadprzyrodzoną mocą istoty nieludzkie, które należało zgładzić i wypić ich krew, by w ten sposób pozbawić je magicznej władzy. Odgrywane przez Amira i Inonga sceny masakry nad Wężową Rzeka, podobnie jak stylizowane rekonstrukcje Anwara Congo i jego kolegów, stanowią - jak uważa Oppen- 
heimer - przykłady aktów performatywnych, których celem jest „oczarowanie” słuchacza i uwiarygodnienie się w jego oczach ${ }^{46}$.

Niewątpliwie opowieści i performanse oprawców pozwalają reżyserowi uchwycić mechanizm indonezyjskiego ludobójstwa, w którym jedna grupa społeczna (komuniści i ich sympatycy) zostaje arbitralnie uznana za niebezpieczną i skazana na śmierć, podczas gdy jej prześladowcy uchodzą za bohaterów. Charakteryzując strategię ataku wyprzedzającego (preemption), Brian Massumi przekonująco uzasadnia, że opiera się ona na strachu, czyli reakcji zachodzącej na płaszczyźnie afektywnej. Zgodnie z obowiązującą w takiej sytuacji logiką postępowania ludzie przystępują do natychmiastowego działania, czyli eliminacji potencjalnego zagrożenia za strony (wyimaginowanego) przeciwnika, którego uznaje się za wcielenie zła ${ }^{47}$. Tworzenie i kontrolowanie afektów należy do zadań polityków, o czym przekonuje zachowanie generała Suharto, który wprawia w ruch machinę propagandową i szuka uprawomocnienia dla ataków prowadzących do unicestwienia wrogów.

Szok, paraliż i niedowierzanie stanowią afektywną odpowiedź prześladowanych na działania podjęte przez oprawców, którzy nieustannie zapewniaja że nie mieli wyboru i musieli uczynić to, co uczynili, ponieważ w przeciwnym razie sami by zginęli. Jeśli czujemy zagrożenie, to znaczy, że ono istnieje - powiada Massumi. Zagrożenie jest afektywnym, samospetniajacym się proroctwem ${ }^{48}$. Nie ma znaczenia, czy komuniści dopuścili się barbarzyńskich czynów, które im zarzucano, ani czy stali za nieudanym zamachem stanu, ponieważ w tym wypadku chodziło o afektywne fakty, które istnieja i działaja na społeczeństwo bez względu na to, czy sa zakorzenione w rzeczywistości, czy też nie $e^{49}$.

Filmy Oppenheimera nie dostarczają gotowych odpowiedzi, lecz prowokują do zadawania dalszych pytań. Po pierwsze, czy odgrywane sceny zbrodni pozwalają spojrzeć na ludobójstwo jako ciąg działań o charakterze performatywnym? Po drugie, jeśli odtwarzanie jest wpisane $w$ akty przemocy oraz inscenizowane jako spektakl, to jaką rolę odgrywają praktyki rekonstrukcyjne w krytycznym podejściu do historii i czy moga przyczynić się do zrozumienia tego, na czym polega ludobójstwo ${ }^{50}$ Po trzecie, w jakim stopniu afektywne reakcje na dzieło sztuki mogą skłaniać do myślenia i wzbudzać emocje oraz w jaki sposób performatywne przedstawienia wchodzą w dialog z innymi rodzajami pamięci? ${ }^{51}$ Po czwarte, w jakim stopniu przeszłość uobecnia się w teraźniejszości i aktualizuje „,widmowe znaczenia" za pomocą powtarzalnych gestów, ruchów i spojrzeń? I wreszcie po piąte, czy performans - jako coś udawanego, odgrywanego - może wywoływać rzeczywiste skutki?

\footnotetext{
${ }^{1}$ Pojęcie postpamięci weszło do dyskursu humanistycznego za sprawą publikacji Marianne Hirsch (m.in. Pokolenie postpamięci, tłum. M. Borowski, M. Sugiera, „Didaskalia” 2011, nr 105, s. 25-36). O filmach przedstawiających doświadczenie traumatyczne drugiego pokolenia pisze Joshua Hirsch, Postmodernizm, drugie pokolenie $i$ międzykulturowe kino posttraumatyczne, tłum. T. Bil-
}

czewski, A. Kowalcze-Pawlik, w: Antologia studiów nad trauma, red. T. Łysak, Universitas, Kraków 2015, s. 253-284.

${ }^{2}$ Do najważniejszych filmów na temat sprawców zbrodni, które powstały w ostatnich latach, należą m.in. Cień uśmiechu (To See If I'm Smiling, reż. Tamar Yarom, 2007), Walc $z$ Baszirem (Vals im Bashir, reż. Ari Folman, 2008), Z32 (reż. Avi Mograbi, 2008), Zwykła 
procedura operacyjna (Standard Operating Procedure, reż. Errol Morris, 2008), Porzadny (Der Anständige, reż. Vanessa Lapa, 2014). Czytelników zainteresowanych tym tematem odsyłam do dwóch książek autorstwa Rayę Morag: Waltzing with Bashir: Perpetrator Trauma and Cinema, I. B. Tauris, London 2013 oraz Perpetrator Cinema: Confronting Genocide in Cambodian Documentary, Columbia University Press, New York 2020.

${ }^{3}$ P. Levi, Pograżeni i ocaleni, tłum. S. Kasprzysiak, Wydawnictwo Literackie, Kraków 2007, s. 101.

${ }^{4}$ Nie miejsce w krótkim artykule filmoznawczym na omawianie politycznych i historycznych kontekstów popełnionych wówczas zbrodni, dlatego zainteresowanych szczegółami odsyłam do artykułu Roberta Cribba Genocide in Indonesia,1965-1966, ,Journal of Genocide Research" 2001, t. 3, nr 2, s. 219-239.

${ }^{5}$ N. Laskowska, Indonezyjskie ludobójstwo, indonezyjskie "odrodzenie" oraz udział Zachodu w fatszowaniu indonezyjskiej historii, w: Azja i Afryka: inność - odmienność - różnorodność, red. P. Bachtin, M. Klimiuk, Wydział Orientalistyczny, Uniwersytet Warszawski, Warszawa 2014, s. 191-192.

${ }^{6}$ Por. B. Machul-Telus, U. Markowska-Manista, Edukacja o ludobójstwach - historia, pamięć, rozumienie, w: Krwawy cień genocydu. Część druga. Ludobójstwa - pamięć, dyskurs, edukacja, red. B. Machul-Telus, U. Markowska-Manista, L. M. Nijakowski, Instytut Wydawniczy Książka i Prasa, Warszawa 2017, s. 39.

${ }^{7}$ P. Bourdieu, J.-C. Passeron, Reprodukcja. Elementy teorii systemu nauczania, tłum. E. Neyman, Wydawnictwo Naukowe PWN, Warszawa 2006, s. 73.

${ }^{8}$ Film ten regularnie wyświetlano w telewizji w rocznicę nieudanego zamachu, a szkoły organizowały obowiązkowe wycieczki do kina (i to pomimo krwawych scen przemocy, które pokazywano w sposób niezwykle dosłowny w celu zobrazowania okrucieństwa komunistów).

${ }^{9}$ Konwencja w sprawie zapobiegania $i$ karania zbrodni ludobójstwa została ratyfikowana przez polski rząd zgodnie z ustawą z 18 lipca 1950 r. W nowych opracowaniach socjologicznych poświęconych temu zagadnieniu przyjmuje się nieco szersze rozumienie kategorii ludobójstwa. Zob. L. M. Nijakowski, Rozkosz zemsty. Socjologia historyczna mobilizacji ludobójczej, Wydawnictwo Naukowe Scholar, Warszawa 2013.
${ }^{10}$ H. Fein, Genocide: A Sociological Perspective, Sage Publications, London 1993, cyt. za: B. Machul-Telus, U. Markowska-Manista, dz. cyt., s. 33. Por. J. Oppenheimer, Show of Force: Film, Ghosts and Genres of Historical Performance in the Indonesian Genocide, University of the Arts, London 2004 (nieopublikowana rozprawa doktorska), s. 3.

${ }^{11} \mathrm{~T}$. Łysak, Od kroniki do filmu posttraumatycznego, Instytut Badań Literackich PAN, Warszawa 2016, s. 79. Zastanawiając się nad sposobami przedstawiania ludobójstwa na ekranie, warto zwrócić uwagę na artykuł André Singera Antropologia, ludobójstwo i obrazowanie, tłum. G. Nadgrodkiewicz, „Kwartalnik Filmowy" 2016, nr 93-94, s. 214-234, w którym autor zestawił twórczość Oppenheimera z filmami o Holocauście, odnosząc się m.in. do nakręconego przez siebie dokumentu Ciemności skryją ziemię (Night Will Fall, 2014).

${ }^{12}$ E. Domańska, Mikrohistorie. Spotkania w międzyświatach, Wydawnictwo Poznańskie, Poznań 2005. Pojęcie mikrohistorii wprowadzili do dyskursu humanistycznego włoscy historycy Carlo Ginzburg i Giovanni Levi.

${ }^{13}$ Tamże, s. 123.

${ }^{14} \mathrm{~W}$ rozmowie $\mathrm{z}$ Irene Lusztig Oppenheimer jednoznacznie określił cele, jakie zamierzał osiągnąć w swoim filmie. Wspominał, że wybrał strategię opowiadania o ludobójstwie odmienną od tej, jaką przyjął Claude Lanzmann w Shoah. Por. I. Lusztig, The Fever Dream of Documentary: A Conversation with Joshua Oppenheimer, „Film Quarterly” 2013, t. 67, nr 2, s. 52.

${ }^{15}$ Por. tamże, s. 53. Wbrew temu, co sugerował sam reżyser i powtarzali niektórzy krytycy, temat zbrodni popełnionych w latach 1965-1966 pojawił się w wielu filmach dokumentalnych nakręconych po 2000 r., m.in. w Masowych grobach (Mass Graves, reż. Lexi Rambadetta, 2001), Prezencie dla matki (Kadountukibu, reż. Rumekso Setiadi, 2004) czy krótkometrażowej fabule Klayaban (reż. Farishad Latjuba, 2004). Więcej informacji na temat dokumentów poświęconych tym wydarzeniom przynosi artykuł Ariela Heryanto Screening the 1965 Violence, w: Killer Images: Documentary Film, Memory and the Performance of Violence, red. J. ten Brink, J. Oppenheimer, Wallflower Press, London 2012, s. 224-240.

${ }^{16}$ R. Schneider, Performing Remains: Art and War in Times of Theatrical Reenactment, Routledge, London 2011, s. 33.

${ }^{17}$ Por. J. ten Brink, J. Oppenheimer, Introduction, w: Killer Images, dz. cyt., s. 7-9. Wiele informacji o współpracy z Oppenheimerem 
przynosi wywiad przeprowadzony przez Andrzeja Pitrusa z Joramem ten Brinkiem Gwiazdy filmowe płacza tylko przez minute, „Kwartalnik Filmowy” 2013, nr 82, s. 105-110 .

18 D. Taylor, Performans, tłum. M. Borowski, M. Sugiera, Universitas, Kraków 2018, s. 141.

${ }^{19} \mathrm{~J}$. Bennett, Wnętrze, zewnętrza: trauma, afekt i sztuka, tłum. A. Kowalcze-Pawlik, T. Bilczewski, w: Pamięć $i$ afekty, red. Z. Budrewicz, R. Sendyka, R. Nycz, Instytut Badań Literackich PAN, Warszawa 2014, s. 146, 154.

${ }^{20}$ R. Schneider, dz. cyt., s. 30.

${ }^{21}$ T. P. Pringle, Documentary Animism: Material Politics and Sensory Ethics in "The Act of Killing" (2012), "Journal of Film and Video" 2015, t. 67, nr 3-4, s. 25.

${ }^{22}$ D. Sajewska, Rekonstrukcja jako profanacja archiwum, „Dialog” 2017, nr 7-8, s. 166, 170.

${ }^{23}$ Rozumienie afektu (affectus) jako ,pobudzenia ciała" proponuje Baruch Spinoza w Etyce; jego koncepcję omawia Gilles Deleuze w książce Spinoza. Filozofia praktyczna, tłum. J. Brzeziński, Wydawnictwo PWN, Warszawa 2014, s. 79-84.

${ }^{24}$ T. Dolasiński, Ludzkie, arcy(nie)ludzkie. Efekt afektu i aktualność podmiotu drugiej nowoczesności, w: Pamięć i afekty, dz. cyt., s 107-108.

${ }^{25}$ J. Oppenheimer, dz. cyt., s. 64, 72.

${ }^{26} \mathrm{~J}$. Butler, Uwikłani w płeć. Feminizm i polityka tożsamości, tłum. K. Krasuska, Wydawnictwo Krytyki Politycznej, Warszawa 2008, s. 252. Teoria performansu w ujęciu Judith Butler należy do najczęściej przywoływanych koncepcji w rozprawie doktorskiej Oppenheimera.

27 Por. B. Nichols, Irony, Cruelty, Evil (and a Wink) in "The Act of Killing”, "Film Quarterly" 2013, t. 67, nr 2, s. 25. Omówienie praktyk rekonstrukcyjnych $\mathrm{w}$ filmach dokumentalnych można znaleźć w innym artykule Billa Nicholsa: Documentary Reenactment and the Fantasmatic Subject, "Critical Inquiry" 2008, nr 35, s. 72-89.

${ }^{28}$ Anwar Congo i jego koledzy otwarcie przyznają się do przynależności do przestępczego półświatka, mówią o sobie preman, czyli wolni ludzie $-\mathrm{z}$ ang. free man, choć $\mathrm{w}$ istocie określenie to pochodzi od holenderskiego słowa vrijman, które pierwotnie odnosiło się do niekontraktowych pracowników Kompanii Wschodnioindyjskiej i dopiero z upływem czasu zaczęto używać go na określenie rzezimieszków. Por. Z. R. Chaudhary, This Time with Feeling: Impunity and the Play of Fantasy in "The Act of Killing", "Boundary 2" 2018, t. 45 nr 4 , s. 83 .
${ }^{29}$ Sarah Ahmed w Performatywności obrzydzenia (tłum. A. Barcz, „Teksty Drugie” 2014, nr 1) pisze, że obrzydzenie jest głęboko ambiwalentne - dotyczy pragnienia albo fascynacji tymi samymi przedmiotami, które odczuwa się jako odrażajace (s. 171) i dalej: odczuwać wstręt to być afektowanym (,"affected") tym, co się odrzuciło (s. 174).

${ }^{30}$ S. Buryła, Portret oprawcy - rzecz do napisania, „Przestrzenie Teorii” 2012, nr 18, s. 98.

${ }^{31}$ E. Willis, Balancing Acts: (Meta)theatricality and Violence, "Performance Research" 2019, t. 24 , nr 4, s. 26 .

${ }^{32}$ L. van Liere, The Banality of Ghosts: Searching for Humanity with Joshua Oppenheimer in "The Act of Killing", "Journal for Religion, Film and Media" 2018, t. 4, nr 1, s. 23-24.

${ }^{33}$ J. Oppenheimer, M. Uwemedimo, Show of Force: A Cinema-séance of Power and Violence in Sumatra's Plantation Belt, w: Killer Images, dz. cyt., s. 294.

${ }^{34}$ Sceny odgrywane przez przebranego za kobietę Hermana Koto, przyjaciela Anwara, przypominają kiczowaty horror ze względu na strumienie krwi, obcięte głowy i akty kanibalizmu.

${ }^{35}$ H. King, Born Free? Repetition and Fantasy in "The Act of Killing”, ,Film Quarterly" 2013, t. 67 , nr 2, s. 34 .

${ }^{36}$ Por. F. Canet, The Filmmaker as Activist, "Popular Communication: The International Journal of Media and Culture" 2018, t. 16, nr 2, s. 159. Skupienie się na relacjach oprawców nie jest czymś wyjątkowym w studiach nad pamięcia, o czym świadczy m.in. numer specjalny kwartalnika „Memory Studies” z 2010 r. (t. 3, nr 2), w którym zamieszczono teksty poświęcone członkom Frakcji Czerwonej Armii, agentom Stasi, powieści Łaskawe Jonathana Littella. Warto również sięgnąć po książkę Haralda Welzera o członkach Einsatzgruppen pt. Sprawcy. Dlaczego zwykli ludzie dokonuja masowych mordów, tłum. M. Kurkowska, Scholar, Warszawa 2010.

37 Por. M. Marszałek, Świadectwo jako performans, "Dialog” 2017, nr 7-8, s. 144-145. Autorka powołuje się na tekst Sibylle Schmidt, Können Täter Zeugnis ablegen? Über Täterzeugenschaft in Joshua Oppenheimers "The Act of Killing" (2012) und "The Look of Silence" (2014), w: Zeugen in der Kunst, red. S. Schmidt, S. Krämer, Wilhelm Fink, Paderborn 2016, s. 195-209. Nie jest to opinia odosobniona, bowiem również Nick Fraser krytykuje film zarówno na płaszczyźnie estetycznej, jak i etycznej. Por. N. Fraser, We Love Impunity, „Film Quarterly” 2013, t. 67, nr 2, s. 21-24. 
${ }^{38}$ Erroll Morris i Werner Herzog w rozmowie na temat filmu Oppenheimera zwracają uwagę właśnie na wspomnianą scenę, uznając ją za najbardziej wstrząsającą w całym filmie. Por. D. Denny, "The Act of Killing": From Fever Dream to the Dream-Work, "Intertexts" 2017, t. 21, nr 1-2, 89-90.

${ }^{39}$ J. Bennett, dz. cyt., s. 148.

${ }^{40}$ H. S. Nielsen, The Politics of Fictionality in Documentary Form: "The Act of Killing" and "The Ambassador", "European Journal of English Studies" 2016, t. 20, nr 3, s. 257-258.

${ }^{41}$ J. Walker, Referred Pain: "The Act of Killing" and the Production of a Crime Scene, "Film Quarterly" 2013, t. 67, nr 2, s. 14-15.

${ }^{42}$ Por. M. Meneghetti, Self-Exculpatory Imaginings: Reenactment and Observation in "The Act of Killing", "Canadian Journal of Film Studies" 2016, t. 25, nr 2, s. 43.

${ }^{43}$ S. Ahmed, dz. cyt., s. 171.

${ }^{44}$ Amir Hasan dowodził jednym ze szwadronów śmierci $w$ regionie Teluk Mengkudu, z zawodu był nauczycielem w szkole podstawowej, później jej dyrektorem, a wreszcie kuratorem oświaty z ramienia Ministerstwa Edukacji. Jego przyjaciel, Inong, pracował jako cieśla na brytyjskiej plantacji kauczu$\mathrm{ku}$.

${ }^{45}$ Homay King (dz. cyt., s. 32) zauważył, że Oppenheimer posłużył się zabiegiem inscenizacyjnym, który z powodzeniem kilka lat wcześniej zastosował Rithy Panh w dokumencie S-21: zabójcza machina Czerwonych Kmerów (S-21, la machine de mort Khmère rouge, 2003), pokazując spotkanie byłych więźniów ze strażnikami.

${ }^{46}$ Tamże, s. 299.

${ }^{47}$ B. Massumi, Ontopower: War, Powers, and the State of Perception, Duke University Press, Durham 2015, s. 13-15.

48 Tamże, s. 191.

${ }^{49}$ J. Tabaszewska, Przeszłe przyszłości. Afektywne fakty $i$ historie alternatywne, "Teksty Drugie" 2017, nr 5, s. 55.

${ }^{50}$ Por. J. Oppenheimer, M. Uwemedimo, dz. cyt., s. 295.

${ }^{51}$ Por. J. Bennett, dz. cyt., s. 148.
Krzysztof Loska
Profesor zwyczajny na Uniwersytecie Jagiellońskim, wiceprezes Polskiego Towarzystwa Badań nad Filmem i Mediami, członek Komitetu Nauk o Sztuce PAN; zajmuje się historią filmu, zwłaszcza kinem azjatyckim. Autor stu pięćdziesięciu artykułów naukowych (publikowanych w „Kwartalniku Filmowym”, „Studiach Filmoznawczych”, „Przeglądzie Kulturoznawczym”, „Ekranach”, „Kulturze Współczesnej”, „Ethosie" i in.) oraz dwunastu książek, m.in.: Dziedzictwo McLuhana - między nowoczesnościa a ponowoczesnościa (2001), Hitchcock: autor wśród gatunków (2002), David Cronenberg: rozpad ciała, rozpad gatunku (2003, wspólnie z A. Pitrusem), Tożsamość i media. O filmach Atoma Egoyana (2006), Poetyka filmu japońskiego (2009), Kenii Mizoguchi i wyobrażnia melodramatyczna (2012), Nowy film japoński (2013), Mistrzowie kina japońskiego (2015), Postkolonialna Europa: etnoobrazy zespótczesnego kina (2016). 


\section{Bibliografia}

Ahmed, S. (2014). Performatywność obrzydzenia (tłum. A. Barcz). Teksty Drugie, 1, SS. 169-191.

Bennett, J. (2014). Wnętrze, zewnętrza: trauma, afekt i sztuka (thum. A. KowalczePawlik, T. Bilczewski). W: Z. Budrewicz, R. Sendyka, R. Nycz (red.), Pamięć $i$ afekty (ss. 145-179). Warszawa: Instytut Badań Literackich PAN.

Bourdieu, P., Passeron, J.-C. (2006). Reprodukcja. Elementy teorii systemu nauczania (thum. E. Neyman). Warszawa: Wydawnictwo Naukowe PWN.

Brink, J. ten, Oppenheimer, J. (2012). Introduction. W: J. ten Brink, J. Oppenheimer (red.), Killer Images: Documentary Film, Memory and the Performance of Violence (ss. 1-11). London: Wallflower Press.

Buryła, S. (2012). Portret oprawcy - rzecz do napisania. Przestrzenie Teorii, 18, ss. 83-99. https://doi.org/10.14746/pt.2012.18.6

Butler, J. (2008). Uwikłani w płeć. Feminizm i polityka tożsamości (thum. K. Krasuska). Warszawa: Wydawnictwo Krytyki Politycznej.

Canet, F. (2018). The Filmmaker as Activist. Popular Communication: The International fournal of Media and Culture, 16 (2), ss. 154-167. https://doi.org/10.1080/15405702.2017.1395030

Chaudhary, Z. R. (2018). This Time with Feeling: Impunity and the Play of Fantasy in „The Act of Killing”. Boundary 2, 45 (4), ss. 65-101. https://doi.org/10.1215/019036597142729

Gribb, R. (2001). Genocide in Indonesia,1965-1966. Fournal of Genocide Research, 3 (2), Ss. 219-239. https://doi.org/10.1080/713677655

Deleuze, G. (2014). Spinoza. Filozofia praktyczna (thum. J. Brzeziński). Warszawa: Wydawnictwo PWN.

Denny, D. (2017). „The Act of Killing”. From Fever Dream to the Dream-Work. Intertexts, 21 (1-2), ss. 89-114. https://doi.org/10.1353/itx.2017.0004

Dolasiński T. (2014). Ludzkie, arcy(nie)ludzkie. Efekt afektu i aktualność podmiotu drugiej nowoczesności. W: Z. Budrewicz, R. Sendyka, R. Nycz (red.), Pamięć i afekty (ss. 107-124). Warszawa: Instytut Badań Literackich PAN.

Domańska, E. (2005). Mikrohistorie. Spotkania w międzyśzoiatach. Poznań: Wydawnictwo Poznańskie.

Fein, H. (1993). Genocide: A Sociological Perspective. London: Sage Publications.

Fraser, N. (2013). We Love Impunity. Film Quarterly, 67 (2), ss. 21-24. https://doi.org/10.1525/fq.2014.67.2.21

Heryanto, A. (2012). Screening the 1965 Violence. W: J. ten Brink, J. Oppenheimer (red.), Killer Images: Documentary Film, Memory and the Performance of Violence (ss. 224-240). London: Wallflower Press.

Hirsch, J. (2015). Postmodernizm, drugie pokolenie i międzykulturowe kino posttraumatyczne (thum. T. Bilczewski, A. Kowalcze-Pawlik). W: T. Łysak (red.), Antologia studiów nad trauma (ss. 253-284). Kraków: Universitas.

Hirsch, M. (2011). Pokolenie postpamięci (tłum. M. Borowski, M. Sugiera). Didaskalia, 105, SS. 25-36.

King, H. (2013). Born Free? Repetition and Fantasy in „The Act of Killing”. Film 2uarterly, 67 (2), ss. 30-36. https://doi.org/10.1525/fq.2014.67.2.30 
Laskowska, N. (2014). Indonezyjskie ludobójstwo, indonezyjskie „odrodzenie” oraz udział Zachodu w fałszowaniu indonezyjskiej historii. W: P. Bachtin, M. Klimiuk (red.), Azja i Afryka: inność - odmienność - różnorodność (ss. 189-195). Warszawa: Wydział Orientalistyczny - Uniwersytet Warszawski.

Levi, P. (2007). Pograżzeni i ocaleni (tłum. S. Kasprzysiak). Kraków: Wydawnictwo Literackie.

Liere, L. van (2018). The Banality of Ghosts. Searching for Humanity with Joshua Oppenheimer in „The Act of Killing”. Fournal for Religion, Film and Media, 4 (1), ss. 1534. https://doi.org/10.25364/05.4:2018.1.2

Lusztig, I. (2013). The Fever Dream of Documentary: A Conversation with Joshua Oppenheimer. Film Quarterly, 67, (2), ss. 50-56. https://doi.org/10.1525/fq.2014.67.2.50

Łysak, T. (2016). Od kroniki do filmu posttraumatycznego. Warszawa: Instytut Badań Literackich PAN.

Machul-Telus, B., Markowska-Manista, U. (2017). Edukacja o ludobójstwach - historia, pamięć, rozumienie. W: B. Machul-Telus, U. Markowska-Manista, L. M. Nijakowski (red.), Krwawy cień genocydu. Część druga. Ludobójstwa - pamięć, dyskurs, edukacja (ss. 21-64). Warszawa: Instytut Wydawniczy Książka i Prasa.

Marszałek, M. (2017). Świadectwo jako performans. Dialog, 7-8, Ss. 141-151.

Massumi, B. (2015). Ontopower. War, Powers, and the State of Perception. Durham: Duke University Press.

Meneghetti, M. (2016). Self-Exculpatory Imaginings: Reenactment and Observation in „The Act of Killing”. Canadian Fournal of Film Studies, 25 (2), ss. 39-61.

Morag, R. (2013). Waltzing with Bashir: Perpetrator Trauma and Cinema. London: I. B. Tauris.

Morag, R. (2020). Perpetrator Cinema: Confronting Genocide in Cambodian Documentary. New York: Columbia University Press.

Nichols, B. (2008). Documentary Reenactment and the Fantasmatic Subject. Critical Inquiry, 35, ss. 72-89. https://doi.org/10.1086/595629

Nichols, B. (2013). Irony, Cruelty, Evil (and a Wink) in „The Act of Killing”. Film 2uarterly, 67 (2), ss. 25-29. https://doi.org/10.1525/fq.2014.67.2.25

Nielsen, H. S. (2016). The Politics of Fictionality in Documentary Form: „The Act of Killing” and „The Ambassador”. European fournal of English Studies, 20 (3), ss. 257-258. https://doi.org/10.1080/13825577.2016.1230389

Nijakowski, L. M. (2013). Rozkosz zemsty. Socjologia historyczna mobilizacji ludobójczej. Warszawa: Wydawnictwo Naukowe Scholar.

Oppenheimer, J. (2004). Show of Force: Film, Ghosts and Genres of Historical Performance in the Indonesian Genocide (niepublikowana rozprawa doktorska). London: University of the Arts.

Oppenheimer, J., Uwemedimo, M. (2012). Show of Force: A Cinema-séance of Power and Violence in Sumatra's Plantation Belt. W: J. ten Brink, J. Oppenheimer (red.), Killer Images: Documentary Film, Memory and the Performance of Violence (ss. 287-310). London: Wallflower Press.

Pitrus, A. (2013). Gwiazdy filmowe płaczą tylko przez minutę. Z Joramem ten Brinkiem rozmawia Andrzej Pitrus. Kwartalnik Filmowy, 82, ss. 105-110.

Pringle, T. P. (2015). Documentary Animism: Material Politics and Sensory Ethics in "The Act of Killing” (2012). Fournal of Film and Video, 67 (3-4), ss. 24-41. https://doi.org/10.5406/jfilmvideo.67.3-4.0024 
Sajewska, D. (2017). Rekonstrukcja jako profanacja archiwum. Dialog, 7-8, ss. 162-170.

Schmidt, S. (2016). Können Täter Zeugnis ablegen? Über Täterzeugenschaft in Joshua Oppenheimers „The Act of Killing” (2012) und „The Look of Silence” (2014). W: S. Schmidt, S. Krämer (red.), Zeugen in der Kunst (ss. 195-209). Paderborn: Wilhelm Fink.

Schneider, R. (2011). Performing Remains: Art and War in Times of Theatrical Reenactment. London: Routledge.

Singer, A. (2016). Antropologia, ludobójstwo i obrazowanie (thum. G. Nadgrodkiewicz). Kioartalnik Filmowy, 93-94, ss. 214-234.

Tabaszewska, J. (2017). Przeszłe przyszłości. Afektywne fakty i historie alternatywne. Teksty Drugie, 5, ss. 48-69. https://doi.org/10.18318/td.2017.5.4

Taylor, D. (2018). Performans (thum. M. Borowski, M. Sugiera). Kraków: Universitas.

Walker, J. (2013). Referred Pain: „The Act of Killing” and the Production of a Crime Scene. Film Quarterly, 67 (2), ss. 14-20. https://doi.org/10.1525/fq.2014.67.2.14

Welzer, H. (2010). Sprazcy. Dlaczego zwykli ludzie dokonuja masozych mordów (thum. M. Kurkowska). Warszawa: Wydawnictwo Scholar.

Willis, E. (2019). Balancing Acts. (Meta)theatricality and Violence. Performance Research, 24 (4), ss. 20-27. https://doi.org/10.1080/13528165.2019.1641319

\footnotetext{
Keywords: genocide; Indonesia; documentary; affect theory; performance

\begin{abstract}
Krzysztof Loska

Memory, Performance and Affects - Genocide in the Films by Joshua Oppenheimer

The starting point for the reflection on Joshua Oppenheimer's films is the concept of performance by Rebecca Schneider - especially her remarks on historical reconstructions - and the theory of affects by Jill Bennett (because the actual effect of performative practices is being "affectively moved"). In the author's reading of The Act of Killing (2012) and The Look of Silence (2014), these historical performances registered by the director, with their ability to affect emotions, i.e. to provoke specific affective reactions (disgust, repulsion, sympathy, fascination), offer a new way in which genocide can be talked about. Starting from the analysis of Oppenheimer's films, the author wonders how the memory of historical events is constructed and reconstructed, to what extent the past exerts influence on the present, and, finally, whether it is possible to observe yourself "from the outside" to face your own affections.
\end{abstract}

